UDK: 658.11:339.1]347.736(497.11:497.7)

DOI: $10.1515 / j c b t p-2016-0019$

Journal of Central Banking Theory and Practice, 2016, 3, pp. $47-59$

Received: 16 March 2016; accepted: 16 June 2016

Kiril Postolov *

Ivan Milenkovic **

Dragana Milenkovic ${ }^{* * *}$

Aleksandra Janeska Iliev ${ }^{* * *}$

\section{Influence of Market Values of Enterprise on Objectivity of the Altman Z-Model in the Period 2006-2012: Case of the Republic of Macedonia and Republic of Serbia}

\begin{abstract}
The Altman's model is a multiple discriminant analysis bankruptcy model that uses ordinarily accepted criteria that may provide a useful decision rule to predict financial distress in firms. In this research, we outline the construction and interpretation of the Z-Score influenced by the stock movement for the period of six years in the Republics of Macedonia and Serbia. Research focuses determining the influence of the market value of companies and if it could be related to potential bankruptcy of companies at specific markets.
\end{abstract}

Keywords: Altman's Z, financial distress, bankruptcy

JEL: GO1 Financial Crises
${ }^{*}$ Faculty of Economics, Skopje

E-mail:

kirilp@eccf.ukim.edu.mk

${ }^{* *}$ University of Novi Sad, Faculty of Economics Subotica, Serbia

E-mail:

ivan.milenkovic@pr.ac.rs

${ }^{* * *}$ University of Pristina, Faculty

of Economics, Kosovska Mitrovica,

Serbia

E-mail:

dragana.milenkovic@pr.ac.rs

${ }^{* * * *}$ Faculty of Economic, Skopje

E-mail:

aleksandra.janeska-iliev@eccf.ukim.edu.mk

\title{
Introduction
}

The subject of this research is to acknowledge the reliability of the AltmanZscore and how it is affected by stock movement, in companies in the Republic of Macedonia and in Serbia. The importance of the Altman Z-score could raise implications related to the performance and financial health of companies. Al- 
though Altman originally developed the Z-Score based on a small sample of manufacturing firms, some research seems to show that it is useful in other areas (AlSulaiti, Almwajeh, 2007). Bankruptcies appear to reveal rapidly and disclosures related to such seem unexpected though the signs may have been signalled for years before the filing takes place. Consequently, a significant interest has been generated in business failure prediction within academia as well as in the finance industry (Odipo, Sitati, 2008). In this line a hypothesis of whether psychological and speculative movement of the value of shares on the stock exchange affect the precision of the score will also be tested. In order to prove or reject the defined hypothesis, we will use data obtained from secondary sources, the movement of the stock exchange index in the period December 2006 - December 2007 and the theoretical model of the Altman Z-score. Also, methods of comparison, synthesis and deduction will be used in the process of defining the conclusions of the research.

The goals of this research are to:

- consider that the psychological and speculative movement of the value of shares on the stock exchange affect the precision of the score.

- indicate that there are no differences between the results obtained from the application of the Altman's Z-score in the enterprises in the Republics of Macedonia and in Serbia

\section{Altman Z-score}

The Altman Z-score is a mixture of five weighted business ratios aiming to estimate the likelihood of financial distress or bankruptcy. The Z-Score was developed in 1968 by Edward I. Altman, which is basically a quantitative balance-sheet method of determining a company's financial strength. A Z-score can be calculated for all non-financial companies and the lower the score, the greater the risk of the company falling into financial distress.

Researchers use different tools such as ratios measuring profitability, liquidity, and solvency, which are considered as significant indicators for the company well-being. However the value or significance of any indicator is not clear since authors cite different ratios as being the most effective signal of forthcoming complications.

One of the classic works in the area of ratio analysis and bankruptcy classification was performed by Beaver (1967). In a real sense, his univariate analysis of a 
number of bankruptcy predictors set the stage for the multivariate attempts, by this author and others, which followed.

According to Beaver (1967), by using his univariate analysis with a number of bankruptcy predictors it could be distinguished between matched samples of failed and nonfailed firms for as long as five years prior to failure. A subsequent study by Deakin (1972) utilized the same 14 variables that Beaver analysed, but he considered them within a series of multivariate discriminant models.

The Z-Score can be characterized as a linear combination of 4-5 common business ratios. These ratios are weighted by coefficients which are estimated by spotting a set of firms which had declared bankruptcy. Thereafter, a matched sample of firms is collected for the surviving firms, with matching by industry and estimated assets. The formula for Z-Score and prediction of bankruptcy was given by Edward I. Altman in 1968. This formula for the Altman Z-Score is helpful in calculating and predicting the probability of a company going into bankruptcy within two years. Studies of the Altman's Z have yielded mixed results, and recent literature questions whether or not the formula, tested in the mid-twentieth century on manufacturing firms, is useful in today's marketplace. (Hayes, et al. 2010) The Altman's $Z$ is one of the best known, statistically derived predictive models used to forecast a firm's impending bankruptcy (Moyer, 2005). The Altman's $\mathrm{Z}$ is a weighted composite of financial indicators relating to profitability, revenue, slack resources, and market return (Altman, 1968).

The Altman's model has the following form:

$\mathrm{Z}=1.2^{\star} \mathrm{X} 1+1.4^{\star} \mathrm{X} 2+3.3^{\star} \mathrm{X} 3+0.6^{\star} \mathrm{X} 4+1^{\star} \mathrm{X} 5$

$\mathrm{X} 1=$ Working Capital/Total Assets

X2 = Retained Earnings /Total Assets

X3 = Earnings Before Interest \&Tax/Total Assets

$\mathrm{X} 4=$ Market Value of Equity/Total Liabilities

X5 = Sales/Total Assets

The indicator X1 shows the effect that liquidity has over the functioning of an enterprise. If X1 is low, then the enterprise will certainly have problems with the payment of its obligations. A higher X1 indicator means the opposite, a higher degree of liquidity.

$\mathrm{X} 2$ - This number ratio shows the relation and measures the relative size of the Retained Earnings in relation to the Total Assets of the enterprise. If this number ratio is low, it is concluded that the company uses more foreign sources for expansion of the material basis and for normal functioning of the company (for 
the payment of obligations etc.). When this number ratio is higher, that leads to a conclusion that the enterprise is financially capable of doing expanded reproduction from its own sources and that it will be capable to pay its obligations.

X3 -Earnings Before Interest \& Tax/Total Assets

This number ratio shows the company's capability to capitalize from its property. Altman thinks that of all ratio numbers, this one has the highest meaning to the functioning and is a display to the financial state of the enterprise.

The X4 indicator is a relation between the Market Value of Equity/Total Liabilities. This number ratio shows the interest of potential investors in the company in relation to the success of its functioning. This indicator is largely dependent on market fluctuations of the value of capital and we focus our research on how this indicator behaves in cases where there are higher fluctuations in stock movements.

And finally, the number ratio X5 shows the relative size of the relation between the total Sales/Total Assets. From this relation it is possible to see the ability of the management to deal with competitive conditions and the ability to achieve sales. A lower value of this indicator means a decreased market share of the company.

The size of $\mathrm{Z}$ is used as a criterion of classification of companies. Altman defined the following borders:

- If the result is over 2.99 , then the company is considered healthy and there is no risk of failure of the company;

- If the result is between 1.81 and 2.99 , then the company is in the so-called "grey" zone, or the possibility of indications that the company may enter the danger zone;

- If the result is below 1.81, then the company is in the danger zone and there is danger of the company failure.

\section{The application of the Altman Z-score in a company in the Republic of Macedonia}

Higher values in the Altman's Z-Score indicate that firms carry out more actions at a fast pace, while low scores indicate that firms carry out few total actions and respond slowly (Ferrier et al., 2002). Within our analysis the practical application of the model is based on the following assumptions: 
1. The company accomplishes the same financial results over the whole period.

2. Market Value of Equity is being changed with the same amount as is shifting of the market indicator in the period December 2006-December 2007.

3. The critical moment is 29 December 2006 - Market Value of Equity is 3,702.54 (MKD).

The following numbers are required in order to calculate the Altman score (in MKD):

Table 1: Necessary values for the calculation of the Altman Z-score

\begin{tabular}{lc}
\hline Sales & $5,027,599,000$ \\
\hline Working Capital & $4,839,717,000$ \\
\hline Total Assets & $8,581,868,000$ \\
\hline Retained Earnings & $2,516,316,000$ \\
\hline Earnings before Interest \& Tax & $431,283,000$ \\
\hline Market Value of Equity & According to the value in the given period \\
\hline Total Liabilities & $1,934,025,000$ \\
\hline Number of Stocks & $1,044,702$ shares \\
\hline
\end{tabular}

Source: Author calculation

Based on the empirical data, we received the following values of the number ratios (critical moment is December 2006):

$Z=0.6767+0.4105+0.1658+1.2+0.5858$

$\mathrm{Z}=\mathbf{3 . 0 3 8 8}$

Conclusion: Considering the fact that the obtained number is 3.0388 , according to Altman, the company is in the "safe" zone.

\section{Analysis of the accuracy of the score based on the stock movements of the value of shares in the case of companies in the Republic of Macedonia.}

We defined that the hypothesis of our research is the, physiological and speculative movement of the value of the shares on the stock exchange affecting the precision of the score. Let's develop that concept. The results of the previous research 
done based on the empirical data obtained from the successful companies are taken into consideration within this research. The obtained values of the number ratios multiplied with the appropriate ponders are the following:

(1.2) $\mathrm{X}_{1}=0.6767$

(1.4) $\mathrm{X}_{2}=0.4105$

(3.3) $\mathrm{X}_{3}=0.1658$

(0.6) $\mathrm{X}_{4}=1.2$

(1.0) $\mathrm{X}_{5}=0.5858$

The sum of the four number ratios, without the one that shows the relation between the Market Value of Equity/Total Liabilities, of the given example is:

(1.2) $\mathrm{X}_{1}=0.6767$

(1.4) $\mathrm{X}_{2}=0.4105$

(3.3) $\mathrm{X}_{3}=0.1658$

(1.0) $\mathrm{X}_{5}=0.5858$

Result: 1.8388

If we compare the number that we get when we use the Altman Z-score integrally and the number that we get when we exclude the market effect (the value of the shares on the market), from the given example, we will see that the difference is big, that is, the number ratio is around $40 \%$ (in the example) from the total number that is obtained.

Because of those reasons, it is interesting to see how the score will react in case of large fluctuations of values of the shares in the market.

For this purpose, we will use the data received from the research of Naumoski (Naumoski, 2012) for the movement of the market indicator in the period of December 2005 - December 2012.

In the period of December 2004 - December 2012, there were large fluctuations of the value of the stock index. If we take 2004 as the base year (31 December), we will see that the value was 1000 . The highest value of the indicator was on the 31 August 2007 when it reached a value of 10057.77 , or 10.0577 (900.577\%) times larger. The value decreased afterwards to 1704.75 (in comparison with the maximal value, it decreases by 84\%) on December 18, 2012.

For the purposes of this research, we will use the value of the market index on 29 December 2006. 
Based on the values of the indicator we have the following values of the shares as at the last day of the following years (2007, 2008, 2009, 2010, 2011 and 2012):

Table 2: Values of shares in the period December 2006 - December 2012

\begin{tabular}{lc}
\hline December 2006 & 3702.54 \\
\hline December 2007 & 7740.79 \\
\hline December 2008 & 2096.16 \\
\hline December 2009 & 2751.88 \\
\hline December 2010 & 2278.92 \\
\hline December 2011 & 1974.86 \\
\hline December 2012 & 1731.18 \\
\hline
\end{tabular}

Source: Naumoski, 2012

Based on the changes of the market value of the shares in the different periods and based on the number of shares, the total values of the share capital in the observed years were:

Table 3: Market value of the share capital in the period December 2006 -December 2012

\begin{tabular}{lc}
\hline Number of shares: 1044702 & $3,868,050,943$ (MKD) \\
\hline December 2006 & $8,086,818,794($ MKD) \\
\hline December 2007 & $2,189,862,544(M K D)$ \\
\hline December 2008 & $2,874,894,539$ (MKD) \\
\hline December 2009 & $2,380,792,281(M K D)$ \\
\hline December 2010 & $2,063,140,191$ (MKD) \\
\hline December 2011 & $1,808,567,208$ (MKD) \\
\hline December 2012 & \\
\hline
\end{tabular}

Source: Authors`calculations

All of the sizes are the same, but values of the shares changed.

Consequently, $\mathrm{X}_{1}$ to $\mathrm{X}_{3}$ and $\mathrm{X}_{5}$ are of the same amount while $\mathrm{X}_{4}$ now has the following values by years: 
Table 4: Values of $\mathrm{X}_{4}$ in the period December 2006- December 2012.

\begin{tabular}{lc}
\hline $\mathrm{X}_{4}$ & \\
\hline December 2006 & 1.2 \\
\hline December 2007 & 2.5088 \\
\hline December 2008 & 0.6794 \\
\hline December 2009 & 0.8919 \\
\hline December 2010 & 0.7386 \\
\hline December 2011 & 0.6401 \\
\hline December 2012 & 0.5611 \\
\hline
\end{tabular}

Source: Authors` calculations

The values of the score now amount to (by the year):

Table 5: Values of the Z-score in the period December 2006 - December 2012

\begin{tabular}{lc}
\hline Z-score & \\
\hline December 2006 & 3.0388 \\
\hline December 2007 & 4.3476 \\
\hline December 2008 & 2.5182 \\
\hline December 2009 & 2.7307 \\
\hline December 2010 & 2.5774 \\
\hline December 2011 & 2.4789 \\
\hline December 2012 & 2.3999 \\
\hline
\end{tabular}

Source: Authors`calculations

From the last table we can see that:

1. In conditions when the other components are constant and when the market value of the share capital is changing, there is a significant change in the value of the Altman Z-score or that affects the trending of financial strength of the company i.e. the shifting from different states - from the company being in the "green zone" passing in the so-called "grey" zone.

2. Based on the calculation of the Altman Z-score, and as a result of the changing of just one component (market value of the share capital), as can be seen in Table 5, we can fully accept the hypothesis that changes of the value of share capital, as a result of movements on the market from various reasons, affects its size significantly and fully. 


\section{Analysis of the accuracy of the score based on the market movements of shares in the case of a company in Serbia.}

We defined that the hypothesis of our research is the physiological and speculative movement of the values of the shares on the stock exchange that affects the precision of the score.

The obtained results of the number ratios multiplied by appropriated weights:

(1.2) $\mathrm{X}_{1}=0.628$

(1.4) $\mathrm{X}_{2}=0.391$

(3.3) $\mathrm{X}_{3}=0.156$

(0.6) $\mathrm{X}_{4}=0.647$

(1.0) $\mathrm{X}_{5}=0.569$

The sum of the four number ratios, without the number X4 in the given example is:

(1.2) $\mathrm{X}_{1}=0.628$

(1.4) $\mathrm{X}_{2}=0.391$

(3.3) $\mathrm{X}_{3}=0.156$

(1.0) $\mathrm{X}_{5}=0.569$

\section{Result: 1.74}

If we compare the results when using the Altman Z-score integrally and the results when excluding the market effect (the value of shares on the market), from the given example, it could be noted that the difference is big so the number ratio is around $27 \%$ (in the example) from the total number obtained.

Because of those reasons, it is interesting to see how the results will respond in case of large fluctuations in the values of shares on the market.

For this purpose, we will use data received from the Belgrade stock exchange for the movement of the stock index in the period December 2006-December 2012 (Belgrade Stock Exchange Reports).

Based on the values of the indicator, we have the following values of the shares as at the last day of the following years (2006, 2007, 2008, 2009, 2010, 2011 and 2012): 
Table 6: Values of the shares in the period December 2006- December 2012

\begin{tabular}{lc}
\hline December 2006 & 1675.2 \\
\hline December 2007 & 2318.37 \\
\hline December 2008 & 568.18 \\
\hline December 2009 & 663.77 \\
\hline December 2010 & 651.78 \\
\hline December 2011 & 499.05 \\
\hline December 2012 & 523.89 \\
\hline
\end{tabular}

Source: Belgrade Stock Exchange Reports

Based on changes of the market value of shares in the different periods and based on the number of shares, the total value of share capital in the observed years amounts to:

Table 7: Market value of the share capital in the period December 2006-December 2012

\begin{tabular}{lc}
\hline Number of shares: $4,329,685$ & $7,253,088,312$ \\
\hline December 2006 & $10,037,811,813$ \\
\hline December 2007 & $2,447,051,368$ \\
\hline December 2008 & $2,873,915,012$ \\
\hline December 2009 & $2,822,002,089$ \\
\hline December 2010 & $2,160,729,299$ \\
\hline December 2011 & $2,268,278,675$ \\
\hline December 2012 & \\
\hline
\end{tabular}

Source: Authors' calculations

Considering the size is the same, still it should be noted that the values of shares changes.

Based on that, the number ratios have the following numbers $\left(\mathrm{X}_{1}\right.$ to $\mathrm{X}_{3}$ and $\mathrm{X}_{5}$ are the same amount) while $\mathrm{X}_{4}$ now has the following values, by years: 
Table 8: Values of $\mathrm{X}_{4}$ in the period December 2006- December 2012

\begin{tabular}{lc}
\hline $\mathrm{X}_{4}$ & \\
\hline December 2006 & 0.647 \\
\hline December 2007 & 0.896 \\
\hline December 2008 & 0.218 \\
\hline December 2009 & 0.256 \\
\hline December 2010 & 0.252 \\
\hline December 2011 & 0.193 \\
\hline December 2012 & 0.202 \\
\hline
\end{tabular}

Source: Authors’ calculation

Considering the previously obtained data, the $\mathrm{Z}$ score is calculated and presented in Table 9 on an annual basis.

Table 9: Values of the Z-score in the period of December 2006- December 2012

\begin{tabular}{lc}
\hline Z-score & \\
\hline December 2006 & 2.391 \\
\hline December 2007 & 2.64 \\
\hline December 2008 & 1.958 \\
\hline December 2009 & 2 \\
\hline December 2010 & 1.99 \\
\hline December 2011 & 1.93 \\
\hline December 2012 & 1.94 \\
\hline
\end{tabular}

Source: Authors`calculations

The following could be summarized from the last table presented:

1. In conditions when the other components are constant and when the market value of the share capital is changing, there is a significant change in the value of the Altman Z-score. Therefore it could be stated that the market value of share capital affects the trending of financial strength of the company, i.e. considering different states - from the company being in the "green zone" snd passing in the so-called "grey" zone.

2. Based on the calculation of the Altman Z-score, by changing just one component (market value of the share capital), which can be seen on the last table, the hypothesis that changes of the value of share capital, as a result of movements on the market due to various reasons, affects its size significantly and could be fully accepted. 


\section{Conclusion}

The term crisis today becomes one of the most used words in everyday life. Unsuccessful businesses have been defined in various ways in efforts to illustrate the formal process threatening businesses or to categorize economic difficulties involved. General terms that can be found in literature are failure, insolvency, default, and bankruptcy that are used as the terms which qualify some of the distress businesses face. Although these terms are sometimes used interchangeably, they are distinctly different in their formal usage. Today, we cannot talk about operating any company without linking it with the problems that emerge as a result of its operation. Some crises are inevitable no matter how well a company is prepared.

Bankruptcies appear to occur rapidly and news about them seems surprizing, although signs may have been in evidence for years before the filing takes place. Certainly, many stakeholders are interested in finding a reliable method to predict bankruptcy and financial distress. Although methods designed to predict bankruptcy events have had mixed reviews, one common bankruptcy prediction method is the Altman's Z-Score formula. Hence, companies aim at establishing an appropriate manner of identifying the symptoms of the initial crisis, and as well as using appropriate indicators which could determine that the company is, or may enter into a crisis.

The analysis in this paper is based on the so-called Altman Z-score, which is created using accounting techniques and founded on an analysis of number ratios. Depending on the movement of its value, it can tell us in which state the company is in ("Safe Zone", "Grey Zone", or "Distress Zone"). The score is calculated based on the results obtained from income statements and balance sheets of companies.

However, within this research, through the application of the Z-score and based on the movement of the market value of shares, we determined that it can have various values. Furthermore, in case that the market value of shares drastically falls, this indicator can indicate crisis or certain vulnerability, despite positive financial indicators such as sales, income, value of assets, etc.

This could indicate that the $\mathrm{Z}$ score is influenced by the market movement of the stock prices, and we consider that the reliability of this indicator can be reduced with it. 


\section{References:}

1. Al-Sulaiti, K.I., Almwajeh, O. (2007), "Applying Altman Z-score model of bankruptcy on service organizations and its implications on marketing concepts and strategies", Journal of International Marketing \& Marketing Research, Vol.32, No.2, pp. 59-74.

2. Altman, E., (1968), "Financial Ratios, Discriminant Analysis and the Prediction of Corporate Bankruptcy," Journal of Finance, vol.34, No. 4, pp.589-609.

3. Altman, E.I. (1968), "Financial ratios, discriminant analysis and prediction of corporate bankruptcy”, Journal of Finance,Vol.23, No.4, pp. 189-209.

4. Altman, E.I. (2006), Corporate financial distress and bankruptcy: Predict and avoid bankruptcy, analyze and invest in distressed debt, Wiley. Hoboken, NJ:.

5. Beaver, W.,(1968), "Alternative Accounting Measures as Predictors of Failure," Accounting Review, Vol.43, No.1, pp.676-683

6. Beaver, W., (1967), "Financial Ratios as Predictors of Failures," in Empirical Research in Accounting, selected studies, 1966 in supplement to the Journal of Accounting Research, pp. 71-111.

7. Deakin, E. B., (1972), "A Discriminant Analysis of Predictors of Business Failure," Journal of Accounting Research, Vol.10, No.1, pp.167-179.

8. Ferrier, W.J., Mac Fhionnlaoich, C., Smith, K.G., \& Grimm, C.M. (2002)." Impact of performance distress on aggressive competitive behavior: A reconciliation of conflicting views",Managerial \& Decision Economics, Vol.23, pp.301-316.

9. Hayes, S.K., Hodge, K.A. and Hughes, L.W. (2010). "A Study of the Efficacy of Altman's Z To Predict Bankruptcy of Specialty Retail Firms Doing Business in Contemporary Times", Economics \& Business Journal: Inquiries \& Perspectives, Vol.3, No.1, pp.130-134.

10. Moyer, S.G. (2005). Distressed debt analysis: Strategies for speculative investors. Ross Publishing, Fort Lauderdale.

11. Наумоски, А. (2013) Проиена на премијата за ризик на акиионерскиот капитал во компаниите во Република Македонија, Економски факултет, Скопје

12. Odipo, M. k, Sitati, A. (2008) "Evaluation of applicability of Altman's revised model in prediction of financial distress: a case of companies quoted in the Nairobi Stock Exchange" 